\title{
Mark 14:62: Substantial compendium of New Testament Christology
}

\author{
Jean Claude Loba Mkole \\ Translation Consultant, Bible Society of the DRCongo \\ Kinshasa-Gombe/DRC
}

\begin{abstract}
The confession in Mark 14:62 seems to be the most comprehensive Christological compendium of a very early Christian community. This passage reveals Jesus' identity as the Christ, Son of God and Son of man. It has a performative meaning that operates not only for Jesus' earthly life and death, but also for his resurrection and parousia: "You will see" (Mark 14:62b). Some theologians portray Jesus Christ as Ancestor or African King. The purpose of this study is to show how far the African concepts of "ancestor" and "king" can be relevant and legitimate in the light of the Christology of Mark 14:62.
\end{abstract}

\section{INTRODUCTION}

The confession in Mark 14:62 seems to be the most comprehensive Christological compendium of a very early Christian community. This passage reveals Jesus' identity as the Christ, Son of God and Son of man. A recent African Christian confession, as conveyed by some theologians, portrays Jesus Christ as "the Ancestor" (Nyamiti 1984) or "the African King" (Manus 1993). How do these titles accord with the Christological compendium of the early Christian Church as found in Mark 14:62? The present study situates itself as an exegetical contribution to the ongoing elaboration of African contextual Christologies. In fact, a contextual Christology implies not only the use of contextual titles or data, but also their Christianization from a biblical perspective. As some

\footnotetext{
${ }^{1}$ I thank Prof J L P Wolmarans for having hosted me when I was preparing this article during my research visit at Rand Afrikaans University, Johannesburg (14 March-3 April 2000) and Rev D van der Merwe Botha for her proofreading.
} 
theologians have convincingly argued, a true contextualization or inculturation is one that lets all the sins of a culture be crucified and allows that culture to become a new creation in Christ (Bimwenyi 1977; 1980:25-26; Matand 1998:164-166; Bediako 1999:12). Put in other terms, an attachment to Christ should lead to the same process of crucifixion: the believer no longer conforms to the world in which he or she lives (Romans 12:1-2) but crucifies it in him or her (Galatians 6:14-15). The process of inculturation or Christianization transforms whoever believes in Christ into an authentic son or daughter of the unique Father. In this regard, I propose to look first at the Christological content of Mark 14:62 and then to examine its relevance for two African contextual Christologies. In other words, the purpose of this study is to show how "African Christological titles" can be appropriate not only for the sake of Africanity, but also in the light of an early and comprehensive New Testament Christology (Mark 14:62).

\section{CHRISTOLOGY OF MARK 14:62}

Mark 14:62 reveals the identity of Jesus as the Christ, Son of God and Son of man. The passage constitutes the climax of the gospel of Mark (Minette de Tillesse 1968:336; Seitz 1973:478; Perrin 1976:81:95; Dupont 1984:224; Edwards 1989:212) and provides the basis of the Christian faith as well (Lagrange 1911/1947:378). In the gospel of Mark, this is the first and only occasion on which Jesus openly confesses his identity. The confession reveals the totality of Jesus' person, including his eschatological manifestation. For Lohmeyer (1967:329), there is no other passage in the New Testament that links together in one act exaltation and parousia as is the case in Mark 14:62. Robinson (1955/56:336) stresses almost the same idea: "This is a saying which, alike in its context and in its content, is of quite crucial importance. It was not only, according to the Synoptics, decisive for the fate of Jesus, but it is literally of unique significance for understanding both His Messianic claim and His expectation of the Parousia."

Some textual and literary problems have to be addressed before starting analysis of the Christological message of Mark 14:62. At the level of textual criticism, Mark 14:62 has been transmitted in two readings: the shorter reading ego eimi and the longer reading su eipas hoti egô eimô. Though all critical editions prefer the shorter reading, some exegetes have challenged that option by arguing in favor of the longer reading as 
the original one: "There is a good reason to think that in xiv.62 Mark wrote su eipas hoti egô eimi, for not only is this reading well attested ( $\theta \mathrm{f}^{13} 5435657001071$ geo arm Or), but also accounts for the text of Matthew and Luke, and illustrates the note of reserve regarding the Messiahship so frequently found in Mark" (Hooker 1967:164; O'Neill 1969:158; Dunn 1983:127).

In opting, however, for the shorter reading, critical editions might be right. The shorter reading has overwhelming support from the point of view of external and internal criticism. It is attested by early second-century witnesses (Old Latin, Irenaeus, Hegesippus), spread in many regions (Alexandria, Caesaria, Western, Syria) and supported by manuscripts of the best quality ( $\$$ B). In the immediate context of Mark 14:62, it fits as a clear answer to the direct question of 14:61: "Are you the Christ?". It is also justified by the reaction in 14:63-64: "Do we still need witnesses? You have heard his blasphemy." This reaction becomes much more understandable only if Jesus' reply to the high priest is a clear answer (Loba Mkole 1995; 1999).

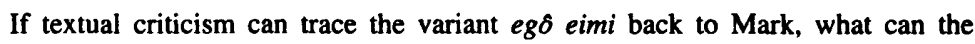
literary criticism say about its authenticity? Does egô eimi go back to Jesus, as the gospel of Mark implies? This declaration is found in the context of Jesus' trial before the Jewish leaders in Jerusalem (Mk 14:53-65 and par). Consequently, its authenticity largely depends on the historicity of that trial. Whereas the debate around this historicity is still open, at least one thing appears certain: the death of Jesus on the cross under Roman procurator Pontius Pilate (Conzelmann 1974:74-75; Perrot 1979:72; Meier 1993:402, 403; Charlesworth 1988:156). Before his crucifixion, Jesus has surely been arrested and interrogated. All four gospels record the Jewish interrogation of Jesus (Brown 1993:556). It is likely that the question of his identity may have been at the center of his interrogation. Therefore, the statement in Mark 14:62 provides, if not the ipsisima verba Jesu, at least the way that, according to the early Christian community, Jesus has or could have spoken about his identity. However, if the question of Jesus' identity might have occupied a central part of the hearing before the Sanhedrin, it does not mean that it is Jesus' confession about his identity that has necessarily compelled Jewish leaders to call for the death penalty. Some negative emotions like envy or jealousy (Mk 15:10) might have motivated religious authorities in their desire for Jesus' death (Mk 3:6; 11:18; 
14:55). Pauw (1997:47-61) has appropriately shown how emotions exert influence upon events in the gospel of Mark. In any case, Mark 14:62 remains "of supreme importance for New Testament Christology, be it concerned with Jesus' own understanding or with that of the early Church as represented by the evangelist Mark" (Kempthorne 1977:197). Its Christological message derives from a particular combination of two assertions: "ego eimi" (ho christos, ho huios tou eulogètou) and kai opsesthe ton huion tou anthrôpou ...

\subsection{Ego eimi (ho christos, ho huios tou eulogêtou)}

Pesch (1977:437) has pointed out that Mark 14:62 looks like an independent confession ("eingenständiges Bekenntnis") because it was formulated without autō. However, the immediate context may also point to it as an answer to the high priest (Mark 14:61). Jesus' statement in Mark 14:62 comes immediately after the high priest's question which is explicitly addressed to Jesus. At the same time, this declaration is immediately followed by the high priest's reaction (Mark 14:63) who really may have understood it as an answer to him. Thus, the formulation of Mark 14:61 (sou ei ho christos, ho huios tou eulogêtou) plays an important role for the understanding of Mark 14:62. It provides the Christological content to ego eimi and gives to Jesus the opportunity to complete the high priest's Christology. Some exegetes have argued that ego eimi is a divine formula that implies Jesus' deity. It actualizes the words of Yahweh in Exodus 3:14 and is often used in the gospels to denote a real or a pretended divine revelation. To support this view, these exegetes refer to Mark 6:50; 13:6; 14:62; Luke 24:39; John 6:35; 8:12 (Johnson 1960:127, 245; Linton 1960: 258-262; Feuillet 1966:5-22, 231-240; Minette de Tillesse 1968:336; Perrin 1968:82; Drewermann 1989:539). According to other exegetes, ego eimi in Mark 14:62 is not in itself a messianic or Christological formula (Stauffer 1956: 88; 1957:130-147; Zimmermann 1960:1-20; 1974:536; Lane 1974:536; Légasse 1974: 77; Gundry 1993:910). Certainly, it is only in connection with the preceding verse (14.61) that the "ego eimi" of Mark 14:62 affirms "Jesus' christhood and divine sonship" (Gundry 1993:12).

Though the immediate context may point to Jesus' declaration as an answer to the high priest's question, we should also keep in mind that this confession goes beyond the high priest's question. Considering the spread of lexical units used in Mark 14:62 (the 
particle "de", the name Ièsous, the verb eipen, the phrases ego eimi and huios tou anthropou) and throughout the gospel of Mark, it seems that the meaning of this verse goes beyond any immediate context. It is the whole narrative of Mark that sheds light on the meaning of Mark 14.62 and vise versa (Loba Mkole 1995). Furthermore, we may add that Mark 14:62 serves as the only valid confession that, from the Markan narrator's perspective, is given by Jesus himself for the benefit of any reader who is willing to listen to what he himself says about his own identity.

\subsection{Jesus as Christ}

By his declaration ego eimi before the Sanhedrin, Jesus affirms his identity as the Christ, Son of God. Jesus' christhood is culturally and religiously based in Judaism. There are three main figures in Jewish messianic expectations" and speculations: "Royal or Davidic Messiah, Priestly Messiah and Prophetic Messiah" (Vermes 1973:135; Dunn 1992:367. 368). In some cases, all these functions were expected to be performed in one figure (Vermes 1973:135). Two more messianic figures can be added: the hidden and revealed Messiah, and the slain Messiah. Referring to the hidden and revealed Messiah, Vermes (1973:137) writes:

According to the first theory, the Messiah was to remain unknown and unrecognized on earth until the divine plan reached maturity.... The second belief, that the Messiah has to be concealed in heaven before being revealed to men [sic] on Earth, underlines the statement in 2 Baruch 30:1 that after accomplishing his earthly mission, he shall return in glory - presumably to heaven whence he came. More clearly, Pseudo-Ezra of 4 Ezra 14:9 was to be "taken up from among men" and remain with the Messiah (my Son)

As far as the slain Messiah is concerned, Vermes (1973:139) indicates:

Sporadic relics survived in rabbinic literature of speculation concerning a Messiah who was to be slain on the eschatological battlefield. This figure, known as the Messiah son of Joseph or the Messiah son of Ephraim, is projected as the unsuccessful commander-in-chief in the first phase war 
against the final enemy, Gog. Exegetically, the notion is connected with Zechariah 12:10-12, 'They shall look on me, on him whom they have pierced .... The land shall wail ...'.

For the early Judeo-Christian communities, most of the Jewish messianic expectations have been fulfilled in the person of Jesus of Nazareth (Perrin 1976:85).

In the gospel of Mark, Jesus is presented and confessed as the Christ (Mark 1:1; $8: 29 ; 9: 41 ; 12: 35 ; 13: 21 ; 14: 61-62 ; 15: 32)$. As Judaism deals with messianic expectations and speculations, the gospel of Mark also reports some speculations about the Christ $(9: 41 ; 12: 35 ; 15: 32)$. But the central issue in the gospel of Mark is its concern about the active presence of one person, Jesus of Nazareth, who, after his death and resurrection, was recognized and confessed as the Christ. As far as the confessional perspective about Christ is concerned, three occurrences (Mark 1:1; 8:29 and 14:62) play key roles in the gospel of Mark. The title Christos in Mark is prominently confessional (Perrin 1976:85). In Mark 1:1, Christos appears as the family name given to Jesus, the content of which is qualified by the epithet Son of God in some textual traditions. In this position, the name Christos "stands" in the context of a superscription which entitles the whole narrative of Mark. In other words, Mark intends introducing the reader to the one called the Christ while explaining how to understand him. In the first part of the gospel (1:1-8:26), no one confesses Jesus as Christ despite his teaching and acting with authority. However, the second part of the gospel (1:27-16:8) provides two significant Christological confessions (Mk 8:29 and 14:61-62) as Juel (1992:451) notes:

Particularly significant are two passages: the 'confessions of Peter' in 8:29 and the question of the high priest in 14:61. The latter passage provides something of a climax to the story .... The exchange between Jesus and the high priest surely provides one of the story's climaxes, ensuring Jesus' death and forcing the Jewish Court to make a decision about the alleged Christ. The place of the title 'the Christ' in such a passage is reason enough to pay particular attention to the epithet. 
In Mark 29, the disciple Peter responds to the challenge concerning the question of Jesus' identity and confesses him as the Christ. In Mark 14:62, Jesus himself confirms his identity as the Christ. Even nowadays, confirmation is a key issue in several aspects of life, for example in trips or accommodation bookings. Mark uses a specific characterization to highlight the content of Christos on the key confessional passages of his gospel. In Mark 1:1 the content of Christos is qualified by Son of God while in 8:29ff it is associated with Son of man. Noteworthy is the fact that in Mark 14:61-62, Christos is connected both to Son of God and Son of man. For Perrin (1974:478), Mark uses "Christ" and Son of God to establish rapport with his readers and then deliberately reinterprets and gives conceptual content to these titles by using Son of man. Perrin (1974:476) assumes that by the use of Son of man, Mark would like to correct a false Christology prevalent in his church and to teach both a true Christology and its consequences for Christian discipleship. However, it can be observed that the use of the term Son of man alone cannot handle the Christological meaning that Mark wants to convey to his reader by means of the three distinct concepts of Christ, Son of God and Son of man. Otherwise, the reader may wrongly conclude that for the gospel of Mark, Christos would have an identical meaning as Son of God and Son of man. The gospel of Mark reminds the reader that calling Jesus the Christ implies some difficulties. After his confession, Peter finds unsustainable the idea of a suffering Messiah. Consequently, Jesus treats him as Satan (Mk 8:33). Having heard a positive answer from Jesus to his own Christological question, the high priests in Mark 14.63-64 tear his undergarments, accuse Jesus of blasphemy and lead the Sanhedrin to send him to death (Juel 1992:451-452). In fact, as Juel (1992:453) says, the Markan Christological story "is predicated on the tension between what everyone thinks and expects of the Messiah and what is in fact the case". Then, "people who confess Jesus as the Christ should keep in mind that Jesus had to suffer and was killed before he rose again" (de Jonge 1988:58).

\subsection{Jesus as Christ, Son of God}

The divine sonship (ho huios tou eulogêtou) of Jesus is the first characterization of his christhood. Ho huios tou elogètou, literally Son of the Blessed one, is a typically reverential circumlocution for Son of God (Anderson 1976:331, see also Weiss 1872/ 
1901:226; Bowman 1965:289; Schnackenburg 1971:278). What does it mean to be the Son of God? In Judaism, the notion of the Son of God in the sense of a begotten Son of God is very strange. However, this title is used for Israel as a nation and for the king of Israel. Manson ( ${ }^{2} 1935 / 1963: 91-92$; Moore :201-211) considers that in the early Judaism the fatherhood of God was applied to Israel in the sense that God is the founder and the creator of Israel (Deuteronomy 32:6; Isaiah 58:16; Malachite 2:10). As Gundry (1993: 899) points out, "in 2 Samuel 7:13 God calls David's seed his son whom 4 Qflor 1:1-13 identifies as the end-time 'shoot of David' (= the Messiah)". However, for Jeremias (1966:25), calling God his Father is restricted only to the king and the personified people of God, prominent in doctrine and piety: "Im alten Testament geht es immer um das Verhältnis Gottes zu Israel. Nur König [oder das personifizierte Volk] wird gelegentlich ein persönliches Verhältnis zu Gott als seinem Vater ausgesagt" (2 Sam 7:14; Ps 2:7; 89:27; Is 63:16; 64:8; Jr 2:27; 3:4). Strotmann (1991:379) in turn writes:

\begin{abstract}
Nicht die individuelle Anrede Gottes mit 'mein Vater' im Vokativ oder gar mit 'abba' ist Massstab für die Intimität und Nähe zwischen Gott als Vater und den Menschen als Sohn oder Tochter, sondern die Art und Weise, in der sich Gott fraglos und selbstverständlich für seine Kinder einsetzt und sich ihrem Wünschen und Bedürfnissen aussetzt.
\end{abstract}

Strotmann's observation might be true regarding biblical texts that refer to the king or people of Israel as Son of God. However, in extra-biblical Jewish literature some individuals address God as "my Father who is in heaven" even though this address is not in vocative mode. Vermes (1993:177-178) indicates the following evidence.

At the end of his famous exposition of Exodus 20:6, R Nathan concludes: "These wounds caused me to be loved by my Father who is in heaven" (Mekh on Ex 20:6, Lauterbach II, 247). ... R Eleazar ben Azariah said: Let no one declare, "I do not desire ... swine flesh or forbidden sex, but one must say, although I desire them, what shall I do since my Father who is in heaven has given me such commandment".

Though these examples are from the Christian period (around $100 \mathrm{CE}$ ), Vermes observes that it is most unlikely that the Jewish sages would have directly borrowed them from the Gospels. With sporadic and questionable exceptions, no rabbinical awareness of 
the Gospels can be proved. Even negative reactions to the New Testament are rare and belong to a relatively late period, the third or rather the fourth century, when the Christian Church already constituted a threat to Judaism (Vermes 1993:8-9). It is then most probable that Son of God might indicate the Israelite king or nation in the Jewish biblical texts whereas in the midrashic literature the title can be used for an individual such as a rabbi.

In the gospel of Mark, Son of God is exclusively attributed to Jesus, the Christ $(1: 1-11 ; 3: 11 ; 5: 7 ; 9: 7 ; 14: 61-62 ; 15: 39)$. Mark calls Jesus the Son of God from the very beginning of his narrative (1:1). During the baptism and transfiguration scenes, the heavenly voice introduces Jesus as "my beloved Son" $(1: 11 ; 9: 7)$. The demons also call Jesus the Son of God $(3: 11 ; 5: 7)$. In the first part of the Markan gospel (1:1-8:26), Jesus' divine sonship is known only by the narrator $(1: 1)$, God $(5: 7 ; 9: 7)$ and the demons $(3: 11$; $5: 7$; cf 1:24). In the second part of the gospel $(8: 27-16: 8)$, this divine sonship is questioned by the high priest (14:61), confirmed by Jesus himself (14:62) and recognized by the centurion (15:39). It has often been observed that Mark's chief emphasis is on the Son of God as one who is to be recognized as Son of God precisely in his death and not simply in his subsequent resurrection and exaltation (Dunn 1980:48). For R Schnackenburg, the list of the occurrences of Son of God in Mark can be extended to 12:6 and 13:32 (Schnackenburg 1994:58):

Das Spektrum erweitert sich, wenn man das Gleichnis von den bösen Winzern hinzunimmt, dass auf Jesus als den 'geliebten Sohn' anspielt (12:6). Schliesslich verlangt die Stelle 13:32 eine Erörterung, wo zwar nicht vom 'Sohn Gottes' die Rede ist, aber absolut 'der Sohn' genannt wird.

Another passage that ought to be mentioned is Mark 14:36, in which Jesus is addressing God as abba. Like "papa" in French (Perrot 1979:280), abba "is a familiar address of a child to his earthly father" (Rowland 1985:255). In that sense it can be rendered by "father dear", "familiar Daddy" or "my own dear father" (Zeitlin 1988:62; Charlesworth 1989:134; Meier 1991:175). For Vermes (1983:42), abba could also be used in solemn, far from childlike situations, for example when Judah threatens the governor of Egypt (his unrecognized brother) saying: "I swear by the life of the head of 
abba, if I draw my sword from the scabbard, I will not return it there until the land of Egypt is filled with the slain (Targum Neofiti to Gen 44:18)". In the Democratic Republic of Congo, a child or an adult may respectfully call not only his or her biological or social father, "papa" but may also call a paternal uncle in the patrilineal system, or a friend of his father, or any elder man "papa". Sometimes, a Congolese woman calls her husband or her father-in-law "papa". The husband, in turn, calls his wife's father and uncles "father".

There is no doubt that the gospel of Mark displays different panels that depict Jesus as the Son of God. For Schnackenburg (1994:59), the title Son of God in Mark serves as a "Deutungskategorie für die irdische Erscheinung und das Wirken Jesu". Vermes (1993:172) already gives more details applicable to the Markan characterization of Jesus as the Son of God:

Taken together the three representations, viz, the divine sonship of the Messiah, the testimony of the heavenly voice, and that of demons and men, clearly demonstrate that Jesus' filial relationship to God was depicted by the creators of the Synoptic tradition, not as part of the general fatherhood of God, but as a phenomenon out of the ordinary deserving special attention.

What deserves special attention for Mark is more likely the fact that Jesus starts his mission as the Son of God $(1: 1,11)$ and dies as the Son of God (15:39) after he has shown and confessed himself to be the Christ, Son of God and Son of man (14:62). What is then the meaning of the Son of man in connection with Jesus' Christhood and divine sonship?

\subsection{Jesus as Christ, Son of God and Son of man}

Having confessed to be the Christ, the Son of God in his first answer ego eimi, Jesus goes on, adding: kai opsesthe ton huion tou anthrơpou ek dexiôn kathèmenon tès dunameơs kaî erchomenon meta tôn nephelôn tou ouranou. In addition to Son of God, the second part of Mark 14:62 qualifies the Christhood of Jesus as Son of man. The topic of the Son of man continues to be one of the most debated subjects in biblical studies, especially in New Testament Christology. So far biblical scholars agree that the New Testament 
Greek ho huios tou anthrōpou derives from a Semitic origin: in classical Greek, ho huios tou anthropou has a sense that is no different from the Hebrew ben adam or the Aramaic bar enasha, both of which designate a male human being (Perrot 1979:243). Bietenhard (1982:226) precisely notes: "Es heisst längst Gesagtes und Bekantes dass der Ausdruckt 'ho huios tou anthropou' im Griechischen nicht gebräuchlich war ... er erklärt sich nur aus semitischen Sprachgebrauch."

The Jewish biblical literature abundantly uses the Hebrew ben adam in Ezechiel (93x) whereas the Aramaic bar enasha only appears in Daniel 7:13. The Septuagint rendered both expressions by anthropos, which means a man, a human being. However, a great number of biblical scholars consider the Danielic Son of man to be the Messiah: the Son of man in Daniel is regarded as the most sublime messianic conception that the Bible offers since he seems to be not a collective character, but a transcendent Messiah with heavenly and divine features (Feuillet 1975:478; Kuzenzama 1990:19:76).

Some extra-biblical writings (1Henoch 46-71; 4Ezra 13:3) have been mustered as supporting the expectation of the Messiah, the Son of man, in Judaism. However, this interpretation goes well beyond the evidence and suggests a high degree of emotional speculation. With other exegetes I hold the Danielic Son of man to be a symbolic expression that refers not to an individual messianic figure, but to the people of Israel, the kingdom of God (Hampel 1990:32.42.63): "Der Terminus ' $k$ 'bar enash' ist also lediglich durch das Bild von den Tieren bedingt und beschreibt in metaphorischer Rede das endzeitliche Gottesvolk Israel. Er hat somit kein Eigengewicht, ist kein Titel, auch keine individuelle Gestalt und hat insofern keine messianische Bedeutung."

This view is supported by Leivestad (1971/72:244; 1982:234), Bietenhard (1982: 337), Coppens (1983:111), Haag (1993:167), Koch (1993:84) and others. Philological research attributes three understandings to $\operatorname{bar}(e) \operatorname{nash}(a)$ a generic sense (every human being), an indefinite sense (someone) and a circumlocutional sense of the first person personal pronoun (I). At all levels it refers to a human being in the third or the first person (auto-reference). Scholars distinguish three sorts of auto-designation: exclusive auto-designation (when the locutor refers to himself alone), inclusive auto-designation (when the locutor refers to himself and to all other human beings) and idiomatic auto- 
designation (when the locutor refers to himself and to a class of persons with whom he identifies himself).

Son of man in the gospel of Mark appears 14 times $(2: 10,28 ; 8: 31,38 ; 9: 9,12$, $31 ; 10: 33,45 ; 13: 26 ; 14: 21 \mathrm{a}, \mathrm{b} ; 41: 62)$. These occurrences have been divided into three groups (Jackson \& Lake 1920:368; Bultmann 1948/1984:31): the eschatological logia $(8: 38 ; 13: 26 ; 14: 62)$, the passion logia $(8: 31 ; 9: 9,12,31 ; 10: 33,45 ; 14: 21 \mathrm{a}, \mathrm{b} ; 41: 62)$ and the logia related to the earthly activity of the Son of $\operatorname{man}(2: 10,28)$. The first part of the Markan gospel (1:1-8:26) counts two passages $(2: 10,28)$ that depict the Son of man as someone having authority: authority to forgive sins $(2: 10)$ and authority to be the master of the Sabbath (2:28). The second part (8:27-16:8) portrays the Son of man in his passion and in his glory. The mystery of suffering-death-and-resurrection of the Son of man is solemnly predicted three times $(8: 31 ; 9: 31 ; 10: 33)$. The suffering alone is described as fact predicted in the Scripture (9:12) or as betrayal by a disciple (14:21a, b) and by enemies (14:41). The resurrection alone is reaffirmed in 9:9 after the transfiguration scene. In 10:45 the Son of man's ministry (his life-death-and-resurrection) is presented as a ransom for many. One may notice that the Son of man's suffering is intrinsically related to his glory. He must (dei) undergo suffering many things, being rejected or betrayed by the religious authorities and even his disciple/s, being killed and yet rising after three days (Hooker 1967:114). His resurrection after three days demonstrates his power and his glory, or, better, the glory and the power of the Father. This is clearly stated in the eschatological logia $(8: 38 ; 13: 26 ; 14: 62)$. It is in the glory of the Father that the Son of man will witness for or against this generation (8:38). He will be seen coming and gathering the elected in great power and glory (13:26-27). He will be seen seated at the right hand of the Power (God) and coming or going with clouds (14:62). When not preceded or accompanied by a preposition (apo, eis) the verb erchomai does not indicate any direction in itself. It can be translated by either coming or going (Nida \& Louw 1992:5). Thus, in Mark 14:62 the participle erchomenon may be better translated as moving: you will see the Son of man seated at the right hand of God and moving with the clouds of heaven. In this sense, the second part of Mark 14:62 may imply a glorious and powerful manifestation of the Son of man (cf the powerful or glorious manifestation of Yahweh in Deuteronomy 4:11; 5:12; 33:26). 
Recently, Telford has argued that Mark identified Jesus with this apocalyptic Son of $\operatorname{man}(1999: 38-41)$ :

In adopting these Son of man sayings, he (Mark) has preserved the connotation of a triumphant, eschatological figure (identified with Jesus), but has qualified the Messianic overtones by stressing the divine necessity of the Son of Man's redemptive suffering and death .... He (Mark) wishes his readers to see more primitive (and, in my opinion, more historical) understandings of Jesus' person (teacher, prophet, healer) 'superseded' by more exalted ones ('Lord', 'Christ', 'Son of man', 'Son of God').

The evangelist demonstrates some reluctance, however, over images of Jesus as royal Son of David or apocalyptic Son of man, rejecting, I believe, the first, and qualifying the second. But Juel has previously demonstrated the contrary. His exegesis of Son of man in the gospel of Mark is in line with the conclusion that most philological critics have reached on the basis of the Aramaic background of the Son of man expression (1992:451):

The expression 'the Son of man' is of course the most frequent epithet in the Gospel. It ought not, however, be considered (as) a title in the same way as 'Christ' and 'Son of God'. It never appears as a predicate in a statement like 'You are the Son of man'. It occurs exclusively on the lips of Jesus. And whatever one may think of pre-Markan tradition, in Mark Son of man is always to be understood as Jesus' self-designation; he uses the expression to refer to himself. Its absence in any assessment of Jesus and its exclusive use as self-reference by Jesus ought to caution against speaking of a Son of man Christology.

In my opinion, the particularity of the Markan Son of man sayings consists in paradoxically relating the authority, suffering and future glory. The Son of man's authority is proclaimed in his earthly activity, denied in his passion, but reaffirmed by his resurrection and eschatological manifestation (Hooker 1967:181). In the gospel of Mark, the "Son of man" expression is exclusively used by Jesus as auto-designation (circumlo- 
cution for "I") and to emphasise his being human (human nature). All of the Son of man occurrences can be replaced by the personal pronoun (first person singular) without changing the intended locutor, Jesus. The human being component is necessary for the understanding of the Son of man expression. Not only does it indicate a human locator, but it also reveals him as someone who can legitimately refer to himself by this expression. The example of 14:62 can suffice as an illustration. The formulation kai opsesthe ton hion tou anthropou ... and kai opsesthe me ... could basically have the same significance, for both refer to the same locator. But the expression "Son of man" tells us more about the locator. Not only does it refer to the locator Jesus, but it also specifies him as a human being. This aspect becomes more important in the context of 14:62 where Jesus has just affirmed himself to be the Christ, the Son of God. By using "Son of man" instead of "me" he claims to be not only the Christ, the Son of God, but also a human being. In so doing he completes the understanding of his christhood which the high priest's question had limited to the divine sonship. Therefore, the kai in the second part of 14:62 is not a simple junction device, but serves to provide additional information. This information concerns not only Jesus' humanity but also that of his interlocutors. The main verb of the clause opsesthe draws the interlocutors' attention to the issue of the future. The expression "you will see me" (mutaniona in Kiswahili, bokomona ngai in Lingala, or vous me verrez in French) might imply one of two things: the great future vengeance of the locutor, or his wonderful future success. The end of the clause kathemenon ex dexiôn tès dunameos kai erchomenon meta tôn nephelôn tou ouranou might briefly refer to the future manifestation of the Son of man in the glory of God and in the eyewitness of all his interlocutors, protagonists as well as antagonists. With the expression "Son of man", Mark underlines human nature as a necessary component of Jesus' person. This expression depicts Jesus as moving from earthly activity to eschatological manifestation and passing through his passion and resurrection. 


\section{AFRICAN CONTEXTUAL CHRISTOLOGIES AND MARK}

\section{4:62}

\subsection{Jesus Christ as the Ancestor}

African theology is taking shape mainly along the lines of a contextualized Christology. Vähäkangas recognizes that the concept of ancestors has recently become one of the most popular topics in African theology, and he mentions some of the leading theologians in this respect: C Nyamiti, B Bujo, F Kabasele, E Penoukou (Vähäkangas 1997:61). Among these theolgians, $\mathrm{C}$ Nyamiti has been characterized as the "most prolific in the thought and development of African Christology" (Manus 1993:60) and as "the one who has elaborated on the issue broadly and most deeply" (Vähäkangas 1997:61). Nyamiti (1994:70; 1996:41-42) portrays Jesus Christ as the Ancestor. He bases his Christological reflections on ancestral beliefs and practices. For him, the ancestral relationship between the living and the dead or between the Supreme Being and humanity on earth comprises five elements: a) kinship, whereby the ancestor is regarded as the source of life for his or her earthly relatives (consanguineous or non-consanguineous); b) superhuman status (usually acquired through death), which indicates the sacred powers of the ancestor and his or her nearness to God: c) mediation, which is the intermediary function the ancestor assumes between God and human kin; d) exemplarity, which qualifies the ancestor's model and recommendable behavior for the living community; e) the right to frequent sacred communication, whereby the living kin honors, through prayers and ritual oblations, the memory of the ancestor (Nyamiti 1996:41-42).

For Nyamiti, Christ is essentially the Ancestor and this ancestorship should be based on the Trinity (1984; 1994:70; 1996:41-42). Apart from mediation, which is not applicable to the Triune God since it would require persons of different ranks, all of the other four elements intrinsic to the ancestral relationship operate within the Trinity. Kinship (Ascendant/Descendant relation) is obvious in the relationship between the Father and the Son: the Father is the Ancestor from whom the Son descends in eternity, while the Son is the Descendant. The sanctity of the Father derives not from death, as in the case of human ancestors, but from his Divinity. As far as exemplarity is concerned, the Father is the "exemplar of His divine Son, who is His perfect image in being and 
activity" (1996:47). Regarding ritual communication within the Trinity, the Holy Spirit accomplishes the spiration of love between the Father and the Son in terms of ancestral Oblation (1996:47). To sum up with Vähäkangas (1997:63), for Nyamiti ancestorship is an element found in God, that is, an element that belongs to God's perfection which is the sum of all possible perfections. As an element of perfection, ancestorship belongs essentially to God since God is essentially perfect (Nyamiti 1977:48): "Human ancestorship is but a faint and imperfect replica of divine ancestorship .... Since this [definition of ancestorship] applies to both God and man, the category 'ancestor' is a pure perfection which does not in itself imply any imperfection."

Jesus Christ is the Ancestor, because he is the Descendant of the Father and, through his obedience, Jesus is much more a model of conduct than a prototype in nature (Nyamiti 1996:51-52). Thus, in a Trinitarian context Christ is considered as having ancestorship as an essential element of his descendancy (Vähäkangas 1997:68).

\subsection{Ancestors in Christian Liturgical Celebrations}

African ancestors are integrated in celebrations of the Eucharist mostly through invocation and in some places by the symbolic act of libation. The Eucharist is conceived as an assembly presided over by Jesus and a festive meal. In an African context all living people and ancestors have to be invited to take part in such an important gathering and meal. This underscores the idea of communion existing between the living and the dead: "L'invocation des ancêtres au coeur droit se situe dans cette même ligne, notamment en ce qui concerne "l'idéal" humain et religieux qu'ils représentent en particulier pour leurs descendants et la communion de vie qu'ils partagent avec eux et finalement avec toute la famille des bienheureux et amis de Dieu, au ciel et sur la terre" (Ndruudjo Ndahura 1995:185).

In the same way, the importance of ancestors among the "Betsimisaraka", the third largest of the twenty ethnic groups of Madagascar, is underlined by Cole (1997:407) who observes that in that tribe ancestors are immanent in daily life, moving in and around the living, watching their descendants and guiding them in their decisions (1997:407). The invocation of ancestors can be found in eucharistic prayer in some African countries like the DRC, Kenya, Nigeria, Malawi (Kabasele Lumbala 1996:52). In a Kenyan eucharistic prayer ancesters are mentioned in these terms: "With the spirits of our 
Ancestors, we ask you to send the Spirit of life to bless and sanctify these offerings." The Nigerian (Igbo) prayer says: "Our Father, the father of our ancestors, we are gathered for praising and giving you thanks with our sacrifice .... You guided our ancestors and all people, you taught them your way .... Remember our brothers and sisters, your kids who are not in this new family yet. In the light of your Spirit, illuminate them so they may see in the Christ the fulfillment of our ancestors' prayers" (Kabasele Lumbala 1996:52-54). During a celebration organized by Association of Member Episcopal Conferences of East Africa (AMECEA) in 1969, ancestors were invoked in a prayer before taking the holy communion: "We thank God. Oh God, we and our ancestors" (Kabasele Lumbala 1996: 46). In the mass celebration prepared in St Merry (Paris) in 1981 by some African students, ancestors from all over the African continent together with ancestors in faith from Ethiopia, Hippone and Uganda were invited to join the assembly (Kabasele Lumbala 1996:38). During the eucharistic celebration called the "Congolese rite"2, ancestors are invoked together with the saints at the beginning of the celebration. The ancestors who are explicitly invoked are the ones from Zimbabwe, Twana, Shoto, Luba, Kongo, Mongo, Rwanda, Benin, Senegal, Niger, Sudan and Kenya (Kabasele Lumbala 1996:3839).

Not every ancestor is invoked, but only the good ones, the ones who with righteous hearts lived an exemplary life, died a natural death and left descendants on Earth (Kabasele Lumbala 1991:118; 1996:63; Ndruudjo Ndahura 1997: 184). This can be the case only in the context of ancestral invocation within a Christian liturgical celebration. In some cases outside of a Christian context, there is no differentiation between good or evil ancestors: both may be invoked by people from their lineage not as good or bad, but only as ancestors. Ancestors, in this case, are regarded just as members of the living family (Osovo Onibere 1981:54; Mpongo 1991:6-11; Ntedika Konde 1998:1-26). In a family context, people respect each other on the basis of consanguinity or alliance. The category of good or bad may not radically affect the blood relationship in some African contexts.

\footnotetext{
2 The "Congolese rite", known before as the "Zairean rite", was born during the time that the DRC was called Zä̈re. The official name was "Missel romain pour les Diocèses du Zaïre". So far, it is the only African rite approved by the Vatican in the Catholic Church. See the decree "Zairensium Diocesium, Prot 1520/85, 30 April 1988, in Notitiae (1988); Conférence Episcopale du Zaïre 1989. Présentation de la liturgie de la messe. Supplément au Missel romain pour les Diocèses du Zaïre. Kinshasa: Centre Interdiocesain, 1989.
} 
Invocation of good ancestors in some African Christian liturgical celebrations underscores the importance of ancestors in the life of the Africans concerned. However, these celebrations have not yet confessed Jesus as Ancestor. Their silence or reluctance about referring to Jesus as Ancestor seems to tell us that "Ancestor" is neither a confessional title, nor a clear, natural and authentic rendering of the person of Jesus as Christ, Son of God and Son of man (true God and true human). In the same way that Son of man is not a confessional title for Jesus Christ, the African title "Ancestor" is not either. Both Son of man and "Ancestor" illuminate Jesus' humanity in a given cultural context, the former in a Semitic context and the latter in the context of an African culture. Nevertheless, "ancestral theology" has the great merit of demonstrating the importance of ancestors in African cultures and even in the economy of salvation. When some African believers call ancestors for celebrating together the name of Jesus (in the glory of the Father and in communion with the Holy Spirit), they find themselves theologically supported.

\subsection{Jesus Christ as the African King}

Manus (Mk 8:29 par) presents Jesus Christ as the African King. His intention is to reinterpret Peter's answer from within an African cultural setting and by means of the data of scientific exegesis of the New Testament (1993:31). Having examined four African kingships (Yoruba, Baganda, Shilluk and Zulu), he points out four components common to African kings: sacrality, rulership (authority), protection and benevolence. His analysis of some biblical texts (Mt 1-2; Lk 1-2; Mk 15; Dn 7:13-14; Ps 92:1-2,5; Ap 1:58; Jn 18:33-37) shows that Jesus was confessed as the Son of David, the expected and anointed king. Furthermore, "in his activities, especially in his healing acts, Jesus recognizes himself as fulfilling the royal ideal" (Manus 1993:210-211). Like African kings, Jesus has a sacred status, acts with authority, protects his disciples and grants them the gift of life. But Manus (1993:233) finds that Jesus contrasts in superiority to the African kings, for his kingship "is of a higher realm". However, for Manus (1993:29, 238), the acceptance of Jesus Christ as the African King "implies making him at home as one who fulfills Africans' spiritual hopes and aspirations". This statement shows clearly that the purpose of Manus's Christology is to welcome Jesus in Africa with expressions rooted in African cultures. But, if Africans successfully integrate Jesus Christ into their 
cultural setting and faith, there will still be room for asking the question "Who is Jesus Christ?" Responding to such a question by saying that Jesus is the African King might be misleading and inappropriate. In African kingships there is no trace of a king called Jesus Christ. Likewise, in the New Testament, Jesus is not identified as an African King. Furthermore, Manus (1993:211) seems to take the title Christ in the narrow sense of king when he depicts Jesus as "anointed Son of God, the Messiah-king". What about the Messiah-prophet and the Messiah-priest which are figures that Jesus Christ also fulfilled? Yet, for Manus, Jesus Christ contrasts sharply with the African kings. How can he then call him "the African king"?

Jesus is already King for whoever believes in him. Therefore, he is King also for African Christian believers. In this regard, it is not necessary to call him "the African king", since this designation is misleading. Moreover, whatever one may read into the content of "African King", the expression may simply render a sense of Jesus as the Son of man.

\section{CONCLUSION}

The Christology of Mark 14:62 is substantial. It is the scriptural foundation of and paradigm for other Christologies. It uses two confessional titles, Christ and Son of God (Son of the Blessed One), to portray the identity of Jesus as someone of divine nature. The same verse also uses a non-confessional idiom, Son of man, to indicate the human nature of Jesus. The divinity and humanity of Jesus are both indicated by means of the clearly expressed terms Jesus the Christ, Son of God and Son of man. They show the highest degree of divinity and humanity reflected in the person of Jesus. The content of the confessional title Son of God and of the idiomatic expression Son of man mutually penetrate one another without any confusion. On the one hand, the divine title of Jesus (Son of God) also points towards his humanity: the one that God reveals as his Son is a human being who has been baptized by John the Baptist: "This one is my beloved Son" (Mk 1:11). The one that the centurion recognizes as the Son of God is a man: "This man was really the son of God" (Mk 15:39). On the other hand, the human title of Jesus (Son of man) also points towards his divinity. It is this very human being who has divine authority over sin and Sabbath (Mk 2:10, 28), who will be seen in divine glory after his 
suffering, death and resurrection $(8: 31,38 ; 9: 9,12.31 ; 10: 33 ; 13: 26 ; 13.26 ; 14: 62)$. However, neither Son of God nor Son of man can alone render the richness and correctness of the meaning conveyed by both. For this reason, I find that Mark 14:62 provides the most comprehensive biblical understanding of the person of Jesus in terms of the Christ of divine and human nature. This is, in my opinion, the point of departure of New Testament Christology that later on was more profoundly developed by the gospels of Matthew, Luke, John and the creeds of Nicea and Chalcedon (Boring 1999:471). Confessing Jesus as the Christ, Son of God and Son of man corresponds to the dogma of two natures in Jesus: divine and human. We should then recognize that this dogma was formulated in the Greco-Roman mythological categories (see Van Aarde 1999a:465).

However, even though mythological categories were used in the Greco-Roman milieu for Christian dogmatic formulae, there is something that historians may point out: behind Christology lies no myth, but the historicity - even if interpreted - of a person who lived in Galilee and died in Judaea in the first third of the first century CE. The raw core of Christology is the cross. Historians can prove that the cross is historical; archeologists may now be able to show us where Jesus was crucified, even though they cannot elicit a confession in a crucified Lord (Charlesworth 1988:156). In the experience of the cross, Jesus understood himself as the climactic and definite fulfiller of the hopes of Israel together with the nations (Hays 1983:174; Meyer 1994: 352).

For Van Aarde, confessing the double nature of Jesus Christ today may mean being "a human person living in total dependence of God". Jesus of Nazareth was such a person. So were, to certain degree, some African ancestors or kings. However, as far as the Jesus Christ of the Easter experience is concerned, "om in absolute afhanklikheid [te] lewe" in God, Ancestor or King, does not seem enough to render the meaning of Christ, Son of God and Son of man. As a matter of fact, whatever content has been granted to the contemporary understanding of Jesus in African contextual theologies, seems to be limited to the meaning of Son of man. With regard to Jesus Christ, the meaning of Son of God cannot be reduced to the one of Son of man and vice versa. For example, to consider Jesus as the Ancestor in an African context is still to portray him within the category of Son of man. In a conversation held with the Omanhene of Akuapem, Bediako (1999:12) recalls his reaction about Jesus as Ancestor: "None of the nananom (ancestors) whom we invoke in libation, can come through a closed door. You must face 
the open door as you call them and pour libation, or they will not come. Only Jesus, Nana Addi Dankwa told me, has resurrected and can come through closed doors. So you see, he is more than ancestors.

Jesus is more than an African ancestor or king because his identity as the Christ, Son of God and Son of man, operates not only during his earthly life and death or after death like an African ancestor or king, but also in his resurrection and parousia: "You will see" (Mk 14:62b). Confessing Jesus as the Christ, Son of God and Son of man as he did himself according to Mark 14:62, may lead the believer to recognize the uniqueness of Jesus Christ whom the early Christian creeds understood in terms of the true God and true man. However, we must also accept that no exegesis has fully succeeded in explaining this uniqueness from the biblical text, nor has a systematic theology exhaustively and meaningfully elaborated on it. While contextual exegesis and dogmatics are carrying on their endeavor in relationship to a contemporary, relevant meaning for Jesus' identity as Christ, Son of God and Son of man, there are at least three more venues that need to be explored about the person of Jesus Christ: practical experiences of Christian love, liturgical celebrations of the name of Jesus and mystical adorations in spiritual life.

\section{Works Consulted}

Anderson, H 1976. The Gospel of Mark. London: Oliphants. (New Century Bible.)

Bediako, K 1999. Gospel and Culture: Some Insights For Our Time From the Experience of the Early Church. Journal of African Christian Thought 2(2), 8-12.

Bietenhard, H 1982. Der Menschensohn - ho huios tou anthrôpou: Sprachliche und religionsgeschichtliche Untersuchungen zu einem Begriff der synoptischen Evangelien I. Aufstieg und Niedergang der römischen Welt II.25.1, 265-350.

Bimwenyi Kweshi, O 1977. Le discours théologique négro-africain: Problèmes des fondements. Paris - Louvain: Présence Africaine.

- 1980. Théandricité du langage théologique africain, in Ngindu Mushete, A (ed). Parole de Dieu et langage des hommes, 25-36. Kinshasa: Facultés Catholiques de Kinshasa. (Collection Théologie Africaine.)

Boring, E M 1999. Markan Christology: God-language for Jesus. New Testament Studies 45, 451-471. 
Bowman, J 1965. The Gospel of Mark: The New Christian Jewish Passover Haggadah. Leiden: Brill.

Brown, R. E 1993. The Death of the Messiah: From Gethsemane to the grave. A Commentary on the Passion Narrative in the Four Gospels I. London: Geoffrey Chapman; New York: Double Day. (The Anchor Bible Reference Library).

Bultmann, R [1948] 1984. Theologie des Neuen Testaments. 11.Aufl. Tübingen: Mohr. Charlesworth, J H 1988. Jesus within Judaism: New light from exciting archeology discoveries. New York: Doubleday. (The Anchor Bible Reference Library.)

Cole, J (1997). Sacrifice, Narratives and Experience in East Madagascar. Journal of Religion in Africa 27, 401-425.

Collins, J 1992. The Son of Man in First-Century Judaism. New Testament Studies 38, 448-466.

Conzelmann, H 1974. Historie und Theologie in den synoptischen Passionsberichten, in Conzelmann H, Theologie als Schriftauslegung: Aufsätze zum Neuen Testament. München.

Coppens, J 1983. Le Fils d'homme vétéro-et intertestamentaire. Leuven: Leuven University Press. (Bibliotheca Ephemeridum Theologicarum Lovaniensium 61.)

De Jonge, M 1988. Christology in context: The earliest Christian response to Jesus. Philadelphia: Westminster Press.

Drewermann, E 1989. Das Markusevangelium, II. 2.Aufl. Olten: Walter.

Dunn, J D G 1980. Christology in the making: A New Testament inquiry into the origins of the doctrine of the Incarnation. London.

- 1983. The messianic secret in Mark, in Tuckett, C (ed), Issues in Religion and Theology, I, 116-131. Philadelphia: Fortress Press.

- 1992. Messianic ideas and their influence on the Jesus of history, in Charlesworth, J $\mathrm{H}$ et al (eds), The Messiah: Developments in earliest Judaism and Christianity, 365-381. Minneapolis: Fortress Press.

Dupont, J 1984. Assis à la droite de Dieu, in Dupont, J, Nouvelles études sur les actes des Apôtres, 210-295. Paris: Cerf. (Lection Divina 118.)

Edwards J R 1989. Markan sandwiches: The significance of interpretations in Markan narratives. Novum Testamentum 31, 193-216. 
Feuillet, A 1966. Les "ego eimi” christologiques du quatrième évangile. Recherches de Science Religieuse 54, 5-22.231-240.

- 1975. Etudes d'exégèse et de théologie biblique. Ancien Testament. Paris: Gabalda.

Gundry, R H 1993. Mark: A commentary on his apology of the cross. Grand Rapids: Eerdmans.

Haag, E 1993. Der Menschensohn und die Heiligen (des) Höchsten: Eine literar-, formund traditionsgeschichtliche Studie zu Daniel 7, in Van der Woude A S (ed), The Book of Daniel in the light of new findings, 137-186. Leuven: Leuven University Press. (Bibliotheca Ephemeridum Theologicarum Lovaniensium 106.)

Hampel, V 1990. Menschensohn und historischer Jesus: Ein Rätselwort als Schlüssel zum messianischen Selbstverständnis Jesu. Neukirchen-Vluyn: Neukirchener Verlag.

Hays, R B 1983. The faith of Jesus Christ: An Investigation of the narrative substructure of Galatians 3:1-4:11. Chico: Scholars Press. (Society of Biblical Literature Dissertation Series 56.)

Hooker, M.D 1967. The Son of Man in Mark: A study of the background of the term Son of man and its use in St. Mark's Gospel. London: Society for Promoting Christian Knowledge.

Jackson, F J F \& Lake, K 1920. The Beginning of the Christianity I. London.

Jeremias, J 1966. Abba: Studien zur neutestamentlichen Theologie und Zeitgeschichte. Göttingen: Vandenhoeck.

Johnson, S E 1960. A commentary on the Gospel According to St Mark. London: Adam. Juel, D H 1992. The Origin of Mark's Christology, in Charlesworth, J M et al (eds). The Messiah: Developments in Earliest Judaism and Christianity. Minneapolis: Fortress Press.

Kabasele Lumbala, F 1991. Christ as Ancestor and Elder Brother, in Schreiter, R J (ed), Faces of Jesus in Africa. New York: Orbis Books. (Faith and Culture Series.)

- (1996). Liturgies africaines: L'enjeu culturel, ecclésial et théologique. Kinshasa: Facultés Catholiques de Kinshasa. (Recherches Africaines de Théologie. Travaux de la Faculté de Théologie 14.) 
Kempthorne, R 1977. The Markan Text of Jesus' answer to the High Priest (Mk xiv 62). Novum Testamentum 19, 197-208.

Koch, K 1993. Messias und Menschensohn: Die zweistufige Messianologie der jüngeren Apokalyptik. Jahrbuch für Biblische Theologie 8, 73-102.

Kuzenzama, K 1990. Le titre johannique du Fils de l'homme: Essai lexicographique. Kinshasa: Facultés Catholiques de Kinshasa. (Recherches Africaines de Théologie 11.)

Lagrange, M.-J [1911] 1947. Evangile selon saint Marc. Paris: Gabalda. (Etudes bibliques.)

Lane, L W 1974. The Gospel according to Mark, the English text with introduction, Exposition and notes. Grand Rapids: Eerdmans.

Légasse, S 1974. Jésus devant le Sanhedrin: Recherches sur les traditions évangeliques. Revue Théologique de Louvain 5, 170-197.

Leivestad, R 1971/72. Exit the Apokaliptic Son of Man. New Testament Studies 18, 243267.

Leivestad, R 1982. Jesus - Messias - Menschensohn: Die jüdischen Heilandserwartungen zur Zeit der ersten römischen Kaiser und die Frage nach dem messianischen Selbstbewusst ein Jesu. Aufstieg und Niedergang der römischen Welt II.21.1, 220-264.

Linton, $O$ 1960/61. The trial of Jesus and the interpretation of Ps CX. New Testament Studies 7, 258-262.

Loba Mkole, J C 1995. Identité de Jésus en Mc 14:62. Unpublished PhD Dissertation. K U Leuven (Faculty of Theology).

- 1999. Disclosure of the Messianic Secret in Mk 14:62? A Text Criticism Response. Neotestamentica 33 (1999).

Lohmeyer, E 1967. Evangelium des Markus. 17.Aufl. Gottingen: Vandenhoeck (Kritisch-exegetischer Kommentar uber das Neue Testament, 1/2.)

Manson, T W [1935]1963. The Teaching of Jesus. Second edition. Cambridge: Cambridge University Press.

Manus, U C 1993. Christ, the African King: New Testament Christology. Frankfurt am Main: Peter Lang. (Studies in the Intercultural History of Christianity 82.) 
Matand, J B 1998. L'herméneutique de l'inculturation dans Ac 15 et Ga 2,11-14, in Kalonda, J (ed), Inculturation de la vie consacrée en Afrique a l'aube du troisième millénaire: Actes du cinquième colloque international, 144-167. Kinshasa: Editions Carmel Afrique..

Meier, J P 1991. A Marginal Jew: Rethinking the historical Jesus, I. New York: Doubleday.

Meyer, B F 1994. Jesus' Ministry and Self-Understanding, in Chilton, B \& Evans, C A (eds), Studying the historical Jesus: Evaluations of the state of current research, 337-352. Leiden: (New Testament Tools and Studies.)

Minette de Tillesse, G 1968. Le secret messianique dans l'évangile de Marc. Paris: Cerf. Moore, G F s a. Judaism in the First Centuries of the Christian Era. Cambridge: Harvard University Press.

Mpongo 1991. Vers une fête chrétienne des ancêtres africains. Cahiers des Religions Africaines 24, 5-18.

Ndruudjo Ndahura, T 1995. Adaptation et inculturation requises pour une eucharistie évangélisatrice: L'expérience du Zaïre. Revue Africaine de Théologie 38, $167-$ 193.

Nida, E A \& Louw, J P 1992. Lexical Semantics of the Greek New Testament. Atlanta.

Kalonda, J (ed), Inculturation de la vie consacrée en Afrique à l'aube du troisième millénaire: Actes du cinquième colloque international, 123-132. Kinshasa: Editions Carmel Afrique.

Nyamiti, C 1977. African tradition and the Christian God, in Spearhead 49. Eldoret: Gaba Publications.

- 1984. Christ as our ancestor: Christology from an African perspective. Gweru: Mambo Press.

-1994. Contemporary African Christologies: Assessment and practical suggestions, in Gibellini, R (ed), Paths of African Theology. Maryknoll, NY: Orbis Books.

- 1996. Trinity from an African ancestral perspective. African Christian Studies 12, 41-42.

O'Neill, J C 1969.The Silence of Jesus. New Testament Studies 15, 153-167. 
Osovo Ønibere, S G A 1981. Christian reaction to indigenous religion in Nigeria: The ancestor factor as a case-in-point. Bulletin de Théologie Africaine 5, 53-59.

Perrin, N 1976. The High Priest's question and Jesus' answer (Mk 14:61-62), in Kelber W H (ed), The Passion in Mark. Studies on Mark 14-16, 80-95. Philadephia..

- 1974. The Christology of Mark, in Sabbe, M (ed), L'Evangile selon Marc: Tradition et Rédaction, 471-485. Leuven: Leuven University Press. (Bibliotheca Ephemeridum Theologicarum Lovaniensium 34.)

Perrot, C 1979. Jésus et l'histoire, Paris: Cerf. (Jésus et Jésus-Christ 11.)

- 1977. Das Markusevangelium, II. Freiburg: Herder. (Herders theologischer Kommentar zum Neuen Testament 2/2.)

Robinson, J A 1955/56. The second coming - Mark XIV.62. The Expository Times 67, 336-340.

Rowland, C 1985. Christian origins: An account of the setting and character of the important Messianic sect of Judaism. London: Society for Promoting Christian Knowledge.

Schnackenburg, R 1971. Das Evangelium nach Markus, II. Düsseldorf. (Geistliche Schriftlesung, 2/1-2.)

- 1994. Die Person Jesu Christi im Spiegel der vier Evangelien. Freiburg: Herder. (Herders theologischer Kommentar zum Neuen Testament, Supplementband 4.)

Seitz, O J F 1973. The future coming of the Son of Man. Studia Evangelica 6, 478-494.

Stauffer, E 1956. Messias oder Menschensohn? Novum Testamentum 1, 81-103.

- 1957. Jesus. Bern.

Strotmann, A 1991. Mein Vater bist du! (Sir 51:10). Frankfurt a Main.

Telford, W.R 1999. The Theology of the Gospel of Mark. Cambridge, N Y: Cambridge University Press. (New Testament Theology.)

Van Aarde, A 1999. Dekonstruksie van dogma: 'n Eietydse ondersoek na die spore van die leer van die twee nature van Jesus. HTS 55(2\&3), 437-470.

- 1999. Matthew 27:45-53 as the turning of the tide in Israel's history. HTS 55(2\&3), 671-692. 
Vähäkangas, M 1997. Trinitarian processions as ancestral relationships, in Charles Nyamiti's theology: A European Lutheran critique. Revue Africaine de Théologie 21, 61-75.

Vermes, G 1973. Jesus the Jew: A historian's reading of the Gospels. London: Collins.

- 1983. Jesus and the world of Judaism. London: Student Christian Movement Press.

- 1993. The Religion of Jesus the Jew. London.

Weiss, B [1872] 1901. Die Evangelien des Markus und Lukas. 9.Aufl. Göttingen. Vandenhoeck (Kritisch-exegetischer Kommentar über das Neue Testament 1/2.)

Zimmermann, H 1960. Das absolute "Ich bin" in der Redeweise Jesu. Trierer Theologische Zeitschrift 69, 1-20. 